\title{
Effects of herbal medicine on acute cough and quality of life in children and their parents - A prospective real life study
}

\author{
Baljosevic I $\mathbf{I}^{1}$, Bajec-Opancina $\mathrm{A}^{1}$, Subarevic $\mathrm{V}^{1}$, Stankovic $\mathrm{K}^{1}$, Novkovic $\mathrm{M}^{1}$, Agic $\mathrm{A}^{2}$ and Filipovic $\mathrm{I}^{3 *}$ \\ ${ }^{1}$ Institute For Mother and Child, Dr. Vukan Cupic, Belgrade, Serbia \\ ${ }^{2}$ AbelaPharm, Belgrade, Serbia \\ ${ }^{3}$ University Children Hospital, Serbia
}

\begin{abstract}
Introduction: Most children have about 4-6 respiratory infections each year. The term "herbal medicine" is used to identify medicinal herbs or some substances obtained from such herbs that help the body to fight different diseases, including infections, and for improving overall health. This research was aimed at assessing the quality of life of children in the acute phase of the respiratory infection, who got natural syrup for the control of cough.
\end{abstract}

Patients and method: The prospective study was conducted at the institute for children. The study included 99 respondents who were given the unique natural syrup for children twice a day for 10 days. The research was done using a questionnaire filled by the parents of children with cough.

Results: After the supplementation it is evident decrease in number of subjects with above various disturbances (cough disturbs night sleep and regular daily activities) and thus quality of life improvement. There is significant improvement of their respiratory secretion characteristics. $70 \%$ of subjects reported improvement of cough symptoms, $27 \%$ no change. Syrup taste children considered as tasty (63\%). It was determined significant positive correlation between children's and parents'/ family life quality during visit.

Conclusion: It can be concluded that after the application of the syrup in conjunction with a therapeutic therapy, the overall quality of life is improved.

\section{Introduction}

Cough is a complex physiological reflex that consists of a violent expiration to release secretions, foreign matter, overcome bronchospasm or relieve diseases of the airways and protect the respiratory system $[1,2]$. Upper respiratory tract infections (URTI), bronchial hyperactivity (BHR), asthma, gastroesophageal reflux disease (GERD) and angiotensin converter enzyme inhibitor therapy, among others, increase the sensitivity of the cough receptors [3-5]. A healthy school-aged child with no history of URTI in the previous 4 weeks can cough up to 34 times a day [6,7]. However, coughing is one of the most common reasons for consultation in routine pediatric practice and becomes very worrying when it persists for a prolonged period of time; it impacts negatively on sleep and daily activities and affects the quality of life of the child and the parents or caregivers [8,9]. Management of cough in children must be carried out in accordance with applicable pediatric guidelines, that are notably different from those used in adults $[10,11]$. In recent years, specific guidelines have been developed for the management of cough in children in America [12], the United Kingdom [13] and Australia and New Zealand [14]. Sometimes there may be more than one underlying cause, and an integral etiological approach to this disease in children is fundamental in order to assign appropriate treatment [15-21].

Cough, more than other symptoms, is disruptive, prevents the sick child and the family from sleeping [22], and might result in frustration. In the absence of effective antiviral treatment for URI, parents try to find products that will relieve cough until the illness resolves.
The term "herbal medicine" is used to identify medicinal herbs or some substances obtained from such herbs that help the body to fight different diseases, including infections, and for improving overall health [22]. More than half of children younger than 12 years of age use 1 or more products in a given week. Over-the-counter (OTC) products, mostly cough and cold medications, account for most medication exposures [23]. Cough and cold preparations usually combine several medications, including antitussives, expectorants, antihistamines, decongestants, and antipyretics such as acetaminophen. Medical herbs, phytotherapy represents an important method of treating and preventing acute respiratory infections. Accordingly, whole plants, plant extracts, essential oils, tea or in the form of capsules or oral suspensions may be used. Since ancient times, our ancestors have recognized the healing properties of various plants, and to this day there is a wide range of pharmacological effects. In order to minimize the symptoms of patients, in addition to standard therapy, it is very desirable and useful to use auxiliary therapy for the better outcome. When propolis is combined, the healing effects of honey, white spleen, fruit of syrup, with $\mathrm{N}$-acetylcisteine (NAC) apart from the mucolytic effect, there is also an

${ }^{*}$ Correspondence to: Ivana Filipovic, University Children Hospital, Serbia, Tel: 38163512678, E-mail: drivanica@yahoo.com

Key words: cough, children, PropoMucil syrup, natural syrup

Received: January 04, 2019; Accepted: January 25, 2019; Published: February 01,2019 
antimicrobial, anti-inflammatory, antibacterial action that contains this supplement. In accordance with the facts presented, this research was aimed at assessing the quality of life of children in the acute phase of the respiratory infection, in which patients, got the unique natural syrup for children, for the suppression and control of cough.

\section{Material and methods}

The prospective study was conducted at the Institute for Mother and Child "Dr Vukan Čupić", Specialist Clinic for Otorhinolaryngology. This study included 99 respondents, average age was $4,71 \pm 2,26$ years (median 4,00, interquartal range 3,0-6,0, range years was from 2-14 years). Respondets were given the unique natural PropoMucil syrup for children. Syrup contains combination of depurated $20 \%$ dry extract of propolis, standardized on $12 \%$ of total polyfenols $(217 \mathrm{mg} / 12 \mathrm{ml})$ with addition NAC $(50 \mathrm{mg} / 12 \mathrm{ml})$, honey, extract of marshmallow and rosehips extract, manufactured by Abela Pharm, Belgrade, Serbia. Children used syrup twice a day in recomenden daily dose for 10 days.

Given the fact that younger children of pre-school age are susceptible to this type of infection, we analyzed the distribution of respondents by age and found that 83 examinees (84\%) were under 7 years of age, while only 16 respondents were 7 years old and over-maximum 14 years children of school age).

The study was attended by slightly more girls, 57 to 42 boys. It was previously found that among the respondents of this study, the number of pre-school subjects is dominated by the number of respondents who, due to the specific way of staying in the collective, are affected by respiratory infections, and that this type of infection is most often associated with cough it develops due to the existence of a secretion that somehow complicates breathing. It was therefore important to determine the number of children going to the collective. The analysis shows that most of the children of the study participants are involved in some form of collective ( $>90 \%)$.

The data was collected using a questionnaire consist of two parts. Demographic data are contained in first part of questionnaire (age, gender, etc). The second part implies duration of symptoms, interval of duration of cough, impact on quality of life of child and safety and taste of syrup application. Also, this part of questions refers to quality of life of parents whose child has cough. On control examination the second part of the cough questionnaire was filled and parents' experiences and opinions on the efficacy and safety of syrups and the quality of life were recorded.

\section{Results}

Children from our current study were about 5 years old (with range of 2-14 years). There were slightly more girls than boys. The most children had averagely 2 cough episodes per month, but for some children this number increases to 5. Children didn't get antibiotic drugs anytime when they have coughing problem, about half times. More than $90 \%$ of children go to nursery school/school. More than $60 \%$ of children have chronic co-morbidity condition. Children in our current study have usually more than 3 respiratory infections per year (more than $80 \%$ of all subjects) and because of that majority of them are absent from school 4-10 days per one acute illness. What was concerning in this data are information about smoking behavior in children's families i.e. more than a half of families have active smokers, even if their children are prone to respiratory infection. Table 1.

Results at the Figure 1 explain the most important aspects from the children's quality of life questionnaires. It is obvious that there is significant improvement regarding quality (characteristics) of their respiratory secretion characteristics i.e. for the majority of them secretion has changed from yellow and sticky to mucous and clear and also distinct number was without secretion after the syrup usage. Along with that come results about cough influence on night sleep and regular daily activities of children. Namely, at the beginning it was obvious that acute respiratory infection and cough disturbs night sleep and regular daily activities in study subjects. After the supplementation it is evident decrease in number of subjects with above-mentioned disturbances and thus quality of life improvement.

Approximately $70 \%$ of subjects reported improvement of cough symptoms, $27 \%$ were without change, although 4 subjects reported worse symptoms after the supplementation. Syrup taste children considered as tasty (63\%), one third of subjects acceptable and just 7 subjects mean that syrup taste is unpleasant. Adverse reaction was evidenced in just one person as nausea symptoms, but there is also a possibility that respiratory secretion causes nausea not to syrup itself. Table 2 .

Second set of questions was devoted to family/parents quality of life during child's illness. Questions were about parents worries, anger, disturbances of family plans, or night-time sleep or regular daily activities. At the beginning great majority of parents feels worry, anger, frustration, anxiety. They also were commonly sleepless, forced to change family plans, and also with disturbed regular daily activities connected with work or home activities. After the natural syrup supplementation this number decreases as child status becomes better (Figure 2).

We want to make some kind of quantification of children's and parents' quality of life so, we have translated rating variables in conditionally quantitative, following established scoring system. Results are presented at the Figure 3.

It was obvious that natural syrup supplementation and along with that children's health status improvement lead to significant increase in children's so as parent's life-quality $(\mathrm{P}<0,001$ for both) (Figure 4$)$.

Correlation analysis showed significant positive correlation between children's and parents'/family life quality during visit, but no significant correlation between children's life quality at the beginning

Table 1. Demographic data

\begin{tabular}{|c|c|c|c|}
\hline Parameter & $\mathrm{Xsr} \pm \mathrm{SD}$ & Median (IQR) & $\begin{array}{l}\text { Minimum- } \\
\text { maximum }\end{array}$ \\
\hline Age (years) & $4.71 \pm 2.26$ & $4.00(3.0-6.0)$ & $2-14$ \\
\hline Gender (girls/boys), n (\%) & \multicolumn{3}{|c|}{$57 / 42(57.6 / 42.4)$} \\
\hline Cough episodes per month & $2.08 \pm 1.09$ & $2.0(1-3)$ & $0-5$ \\
\hline $\begin{array}{l}\text { Average number of prescribed } \\
\text { antibiotic drug }\end{array}$ & $1.15 \pm 0.825$ & $1.0(1-2)$ & $0-3$ \\
\hline $\begin{array}{l}\text { Children in nursery school/ } \\
\text { school } \\
\text { vs. children at home }\end{array}$ & \multicolumn{3}{|c|}{$92 / 7(92.9 / 7.1)$} \\
\hline Co-morbidity, chronic yes/no & \multicolumn{3}{|c|}{$67(67.7) / 32(32.3)$} \\
\hline $\begin{array}{l}\text { Number of respiratory } \\
\text { infections/year } \\
>3 \\
<3\end{array}$ & \multicolumn{3}{|l|}{$\begin{array}{l}83(83.8) \\
16(16.2)\end{array}$} \\
\hline \multicolumn{4}{|c|}{ Absence from nursery school/school caused by respiratory infections } \\
\hline $\begin{array}{l}\leq 3 \text { days } \\
4 \text { days }-10 \text { days } \\
>10 \text { days }\end{array}$ & $\begin{array}{l}28(28.3) \\
51(51.5) \\
20(20.2)\end{array}$ & & \\
\hline \multicolumn{4}{|l|}{ Smoking behavior in family } \\
\hline Yes/no & \multicolumn{3}{|c|}{$53(53.5) / 46(46.5)$} \\
\hline
\end{tabular}



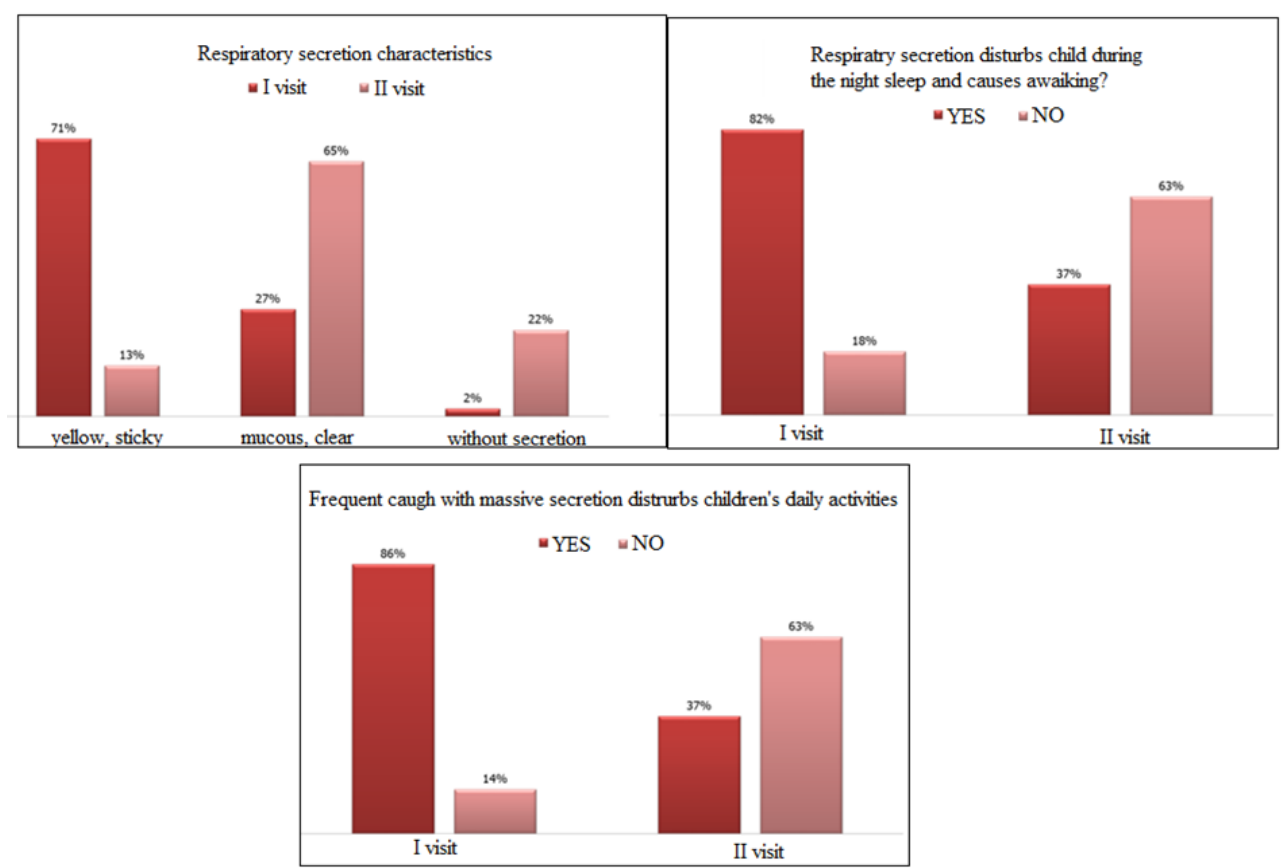

Figure 1. Number of patients according to their respiratory secretion characteristics, night sleep and daily activities disturbances caused by cough before and after natural syrup usage; the insight in children's life quality from the several specific questions

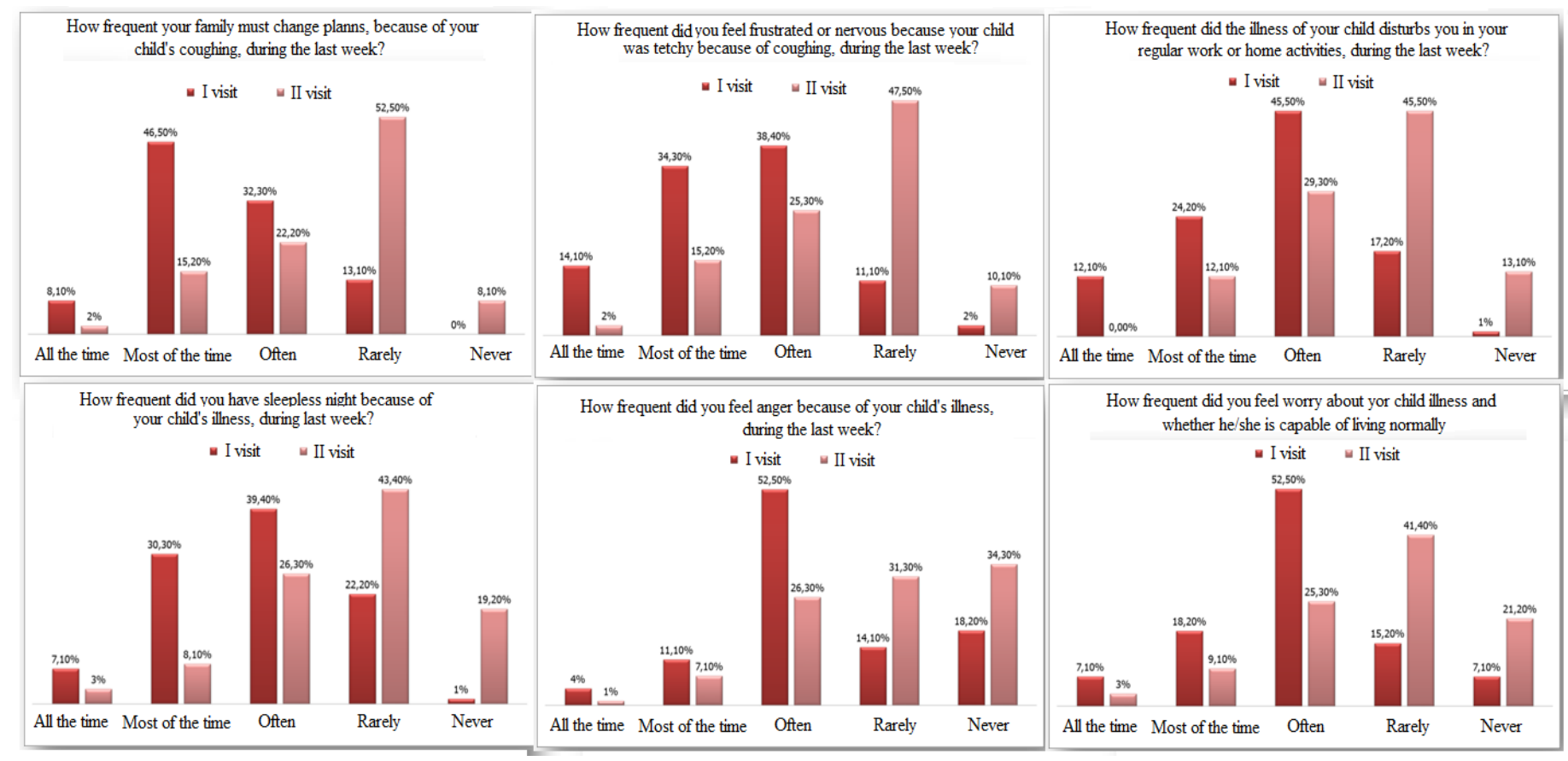

Figure 2. Family (parents) quality of life in relation of child's illness (coughing) before and after the natural syrup usage

Table 2. Data about children's attitude about syrup, adverse reactions and cough symptoms during and after the natural syrup usage

\begin{tabular}{|c|c|c|c|}
\hline \multirow{2}{*}{ Syrup taste, n (\%) } & Tasty & Acceptable & Unpleasant \\
\hline & $62(63)$ & $30(30)$ & $7(7)$ \\
\hline \multirow{2}{*}{$\begin{array}{c}\text { Subject's status regarding } \\
\text { cough symptoms } \\
\mathrm{n}(\%)\end{array}$} & Better & Without change & Worse \\
\hline & $68(69)$ & $27(27)$ & $4(4)$ \\
\hline \multirow{2}{*}{$\begin{array}{c}\text { Adverse reactions } \\
\mathrm{n}(\%)\end{array}$} & \multicolumn{2}{|c|}{ No } & Yes \\
\hline & $98(95)$ & \multicolumn{2}{|c|}{$1(5)$} \\
\hline
\end{tabular}




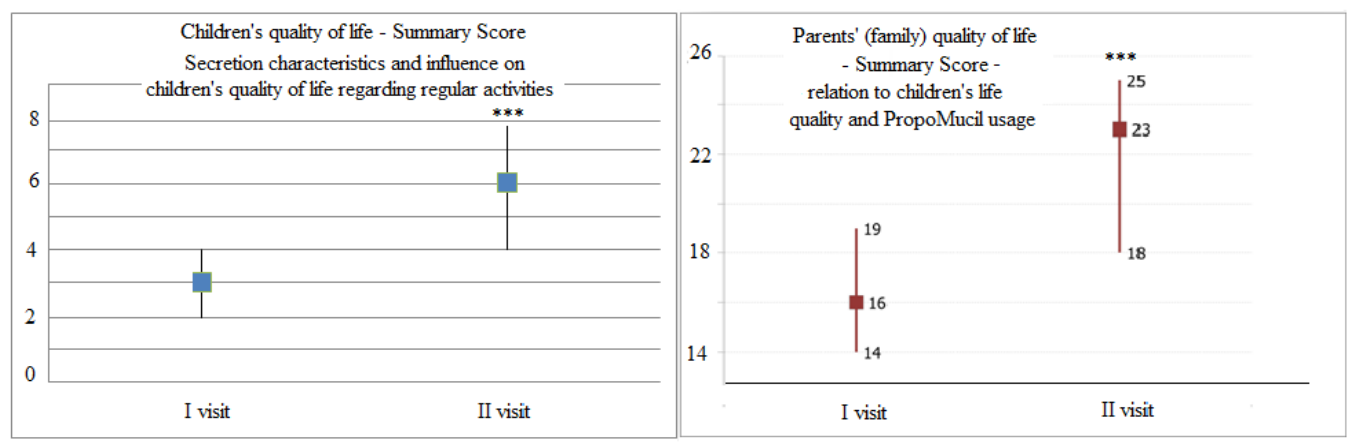

Figure 3. Children's and parents' life quality presented as summary scores, both before and after natural syrup usage "*"- $\mathrm{P}<0.001$, Mann-whitney U test
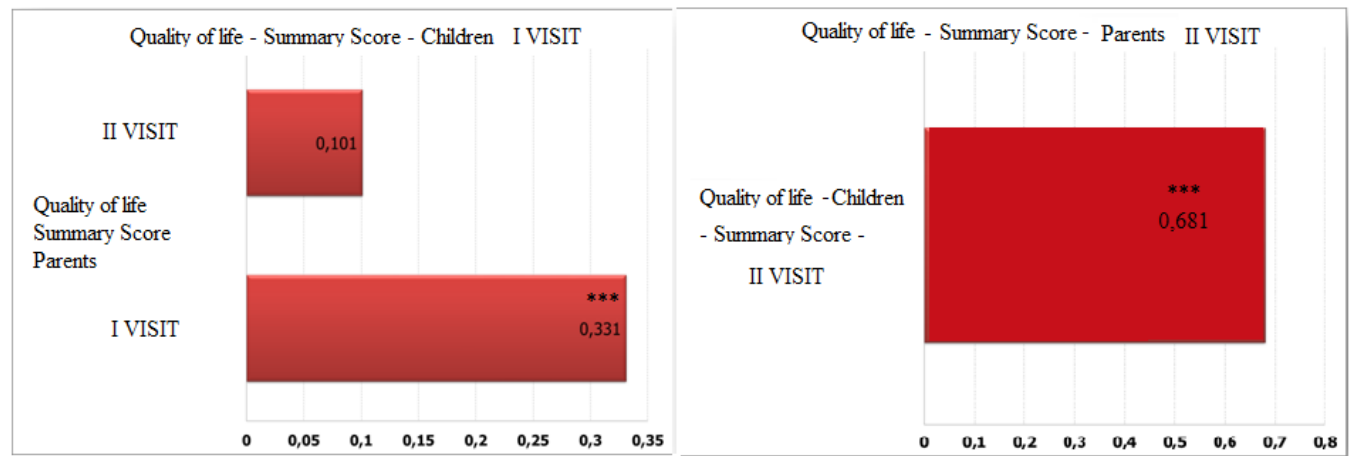

Figure 4. Correlation between children's and parents' quality of life estimated through the summary scores

and parent's life quality at the end of the study. This make a space for an idea about significant modification of these relations caused by natural syrup usage. The most impressive result from this part of analysis was strong positive correlation between quality of life of two groups of subjects (children and parents)-which again confirms cause-and-effect relationships modulated by natural syrup.

\section{Discusion}

In this study, children used natural syrup, $90 \%$ of children went to the collective and more than $60 \%$ had active smokers. After a tenday syrup application, a significant improvement in the respiratory secretion and in the quality of life, both for children and parents, has been demonstrated. The number of night cough has decreased, and the daily life has improved. In $63 \%$ of respondents, the taste is acceptable, while $7 \%$ taste is unsuitable. The most impressive result was strong positive correlation between quality of life of two groups of subjects (children and parents)-which again confirms cause-and-effect relationships modulated by natural syrup. The results from our study are in accordance with the results from similar studies [23,24].

It can be concluded that after the application of the syrup, the overall quality of life is improved, which is very important, because it is a syrup on a natural base used in conjunction with a therapeutic therapy. This study has shown that the use of a multicomponent natural preparation is quite rational with a positive patient outcome.

\section{References}

1. McCool FD, Leith DE (1987) Pathophysiology of cough. Clin Chest Med 8: 189-195. [Crossref]

2. Irwin RS, Baumann MH, Bolser DC, Boulet LP, Braman SS, et al. (2006) Diagnosis and management of cough executive summary: ACCP evidence-based clinical practice guidelines. Chest 129: 1-23. [Crossref]
3. Chang AB (1999) Cough, cough receptors, and asthma in children. Pediatr Pulmonol 28: 59-70. [Crossref]

4. Brodlie M, Graham C, McKean MC (2012) Childhood cough. BMJ 344: e1177. [Crossref]

5. Chang AB, Phelan PD, Sawyer SM, Del Brocco S, Robertson CF (1997) C ough sensitivity in children with asthma, recurrent cough, and cystic fibrosis. Arch Dis Child 77: 331-334. [Crossref]

6. Shann F (1996) How often do children cough? Lancet 348: 699-700. [Crossref]

7. Munyard P, Bush A (1996) How much coughing is normal? Arch Dis Child 74: 531534

8. Marchant JM, Newcombe PA, Juniper EF, Sheffield JK, Stathis SL, et al. (2008) What is the burden of chronic cough for families? Chest 134: 303-309. [Crossref]

9. French CL, Irwin RS, Curley FJ, Krikorian CJ (1998) Impact of chronic cough on quality of life. Arch Intern Med 158: 1657-1661. [Crossref]

10. Irwin RS (2006) Introduction to the diagnosis and management of cough: ACCP evidence-based clinical practice guidelines. Chest 129: 25-27. [Crossref]

11. Chang AB (2010) Pediatric cough: children are not miniature adults. Lung 188: 33-40. [Crossref]

12. Chang AB, Glomb WB (2006) Guidelines for evaluating chronic cough in pediatrics: ACCP evidence-based clinical practice guidelines. Chest 129: 260-283. [Crossref]

13. Shields MD, Bush A, Everard ML, McKenzie S, Primhak R, British Thoracic Society Cough Guideline Group (2008) BTS guidelines: Recommendations for the assessment and management of cough in children. Thorax 63: iii1-1iii15. [Crossref]

14. Chang AB, Landau LI, van Asperen PP, Glasgow NJ, Robertson CF, et al. (2006) Cough in children: definitions and clinical evaluation. Med J Aust 184: 398-403. [Crossref]

15. Gibson PG, Chang AB, Glasgow NJ, Holmes PW, Katelaris P, et al. (2010) CICADA: Cough in children and adults: Diagnosis and assessment. Australian cough guidelines summary statement. Med J Aust 192: 265-271.

16. Asilsoy S, Bayram E, Agin H, Apa H, Can D, et al. (2008) Evaluation of chronic cough in children. Chest 134: 1122-1128. [Crossref] 
17. Marchant JM, Masters IB, Taylor SM, Cox NC, Seymour GJ, et al. (2006) Evaluation and outcome of young children with chronic cough. Chest 129: 11321141. [Crossref]

18. Khoshoo V, Edell D, Mohnot S, Haydel R Jr, Saturno E, et al. (2009) Associated factors in children with chronic cough. Chest 136: 811-815. [Crossref]

19. Rank MA, Kelkar P, Oppenheimer JJ (2007) Taming chronic cough. Ann Allergy Asthma Immunol 98: 305-313. [Crossref]

20. Ramanuja S, Kelkar P (2009) Habit cough. Ann Allergy Asthma Immunol 102: 91-95. [Crossref]
21. Chang AB, Berkowitz RG (2010) Cough in the pediatric population. Otolaryngol Clin North Am 43: 181-198. [Crossref]

22. Paul IM, Beiler J, McMonagle A, Shaffer ML, Duda L, et al. (2007) Effect of honey, dextromethorphan, and no treatment on nocturnal cough and sleep quality for coughing children and their parents. Arch Pediatr Adolesc Med 161: 1140-1146. [Crossref]

23. Larson M (1992) Clinical recognition of N-acetyl cysteine in chronic bronchitis. Eur Respir Rev 2: 5-8.

24. Stey C, Steurer J, Bachmann S, Medici TC, Tramèr MR (2000) The effect of oral $\mathrm{N}$-acetylcysteine in chronic bronchitis: a quantitative systematic review. Eur Respir $J$ 16: 253-262. [Crossref]

Copyright: (C2019 Baljosevic I. This is an open-access article distributed under the terms of the Creative Commons Attribution License, which permits unrestricted use, distribution, and reproduction in any medium, provided the original author and source are credited. 